RESEARCH NOTE

\section{Influence of Preparation Methods on the Dimensions of Lutzomyia intermedia (Lutz \& Neiva, 1912) (Diptera, Psychodidae, Phlebotominae)}

\section{Carlos Brisola Marcondes $/{ }^{+}$, Aloísio Falqueto*, Ana Leuch Lozovei**}

Departamento de Microbiologia e Parasitologia, Centro de Ciências Biológicas, Universidade Federal de Santa Catarina, Campus Trindade, 88040-900

Florianópolis, SC, Brasil *Centro Biomédico, Universidade Federal do Espírito Santo, Vitória, ES, Brasil **Departamento de Patologia Básica, Setor de Ciências Biológicas, Universidade Federal do Paraná, Curitiba, PR, Brasil

Key words: Lutzomyia intermedia - preparation method - Berlese's fluid - sandfly

Morphometry was fundamental for the characterization of phlebotomine sandflies (e.g. R Newstead 1911 Bull Ent Res 2: 47-78). After the discovery of the importance of female cibarium, spermathecae and its ducts (S Adler \& O Theodor 1926 Ann Trop Med Parasitol 20: 109-142), it became less used. However, the great number of sandfly species, some of them very similar, and studies of variations related to season or locality induced a need of studies of measurements.

The preparation method can have some influence on dimensions, as observed for the palpal segments (A Dampf 1947 Ann Esc Nacc Cien Biol 4: 423-435), but the wings were considered undeformable (AL Tonnoir 1935 Bull Ent Res 26: 137-147).

We compared by ANOVA 39 measurements in insects of each sex of L. intermedia, identified according to CB Marcondes (1996 Mem Inst Oswaldo Cruz 91: 457-462), mounted with Berlese's or NC (Nelson Cerqueira, Enecê in Portuguese) (NL

\footnotetext{
${ }^{+}$Corresponding author. Fax: +55-48-331.9258. E-mail: cbrisola@mbox1.ufsc.br Received 7 July 1997

Accepted 24 September 1997
}

Cerqueira 1943 Mem Inst Oswaldo Cruz 39: 3741) fluids. The NC method included dehydration by a series of growing concentrations of ethanol and was detailed by CB Marcondes (1997 Mem Inst Oswaldo Cruz 93: in press). Insects were collected by light traps at the municipality of Venda

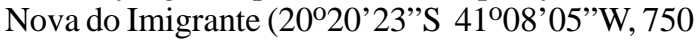
$\mathrm{m}$ a. s. 1.), in the State of Espírito Santo, in December 1994.

Tables I and II show, respectively, the measurements which differed significantly in females and males. All measurements are in $\mathrm{mm}$.

The preparation method significantly affected several measurements, including some in the wings. Our results indicate the need to use a factor of conversion to several measurements, before any comparison of insects prepared by different methods. LMN Passerrat de Silans et al. (1996 Ann Trop Med Parasitol 90: 543-550) considered that the preparation method had effect only on $\mathrm{d}$ and $\mathrm{p}$ (distance between the bifurcation of $\mathrm{R}_{2+3}$ and $\mathrm{R}_{4}$ and that of $\mathrm{M}_{1+2}$ ). They dehydrated the wings before mounting them in chloral balm or Euparal, and did not inform the preparation method for using Hoyer's fluid. This is a modification of Berlese's fluid, so the preparation would probably not include dehydration.

The fifth palpal segment, in Phlebotomus baduelensis Floch \& Abonnenc, $1944[=L$. trinidadensis (Newstead, 1922), AV Martins et al. (1978 American Sand Flies, Acad Bras Ciências, Rio de Janeiro, 195 pp.)], had a 8 to $20 \%$ reduction, after dehydration and inclusion in Canada balsam, compared to the length in lactophenol (Dampf 1947 loc. cit.). In L. intermedia palps, only the total length in males presented smaller size in the mounting with $\mathrm{NC}$, with a mean reduction of only $3.8 \%$.

In this study, all sandflies were preserved dry; the influence of the method of preservation, dry or in $70^{\circ} \mathrm{GL}$, in the measurements should be evaluated. DC Lasenby et al. (1994 J Plankton Res 16: 1601-1608) noted that measurements of Chaoborus $\mathrm{sp}$. were affected by the preservative liquid.

The shrinkage of soft structures, like the spermathecae, would be more common using preparation methods involving dehydration (P Williams 1988 Mem Inst Oswaldo Cruz 83: 375-383). However, in this study, it was observed that shrinkage occurred much more frequently using Berlese's fluid; several of these insects had the spermathecae and ducts difficult to visualize. E Abonnenc (1972 Les Phlébotomes de la Région Éthiopienne, ORSTOM, Paris, 289 pp.) considered the use of chloral hydrate fluids inadequate for humid climates and RP Lane 1993 Sandflies (Phlebotominae), p. 78-119. In RP Lane, RW Crosskey 
(eds) Medical Insects and Arachnids, Chapman \& Hall, London, $x v+723$ pp.] recommended the use of Berlese's fluid, but considered it inadequate for long-term preservation.

Potash at $10 \%$, used in both methods, was probably less harmful to the spermathecal ducts than at $20 \%$, which would be bad to these ducts [DJ Lewis 1982 Bull Brit Museum (Nat Hist) 45: 121-209, N
Léger et al. 1983 Ann Parasitol Hum Comp 58: 611-623]. Potash could turn invisible the membrane involving the spermathecae of $L$. dasymera (Fairchild \& Hertig, 1961) and L. shannoni (Dyar, 1929) (GB Fairchild \& M Hertig 1961 Ann Entomol Soc America 54: 237-255). It would be convenient to examine the flies in phenol, before using potash.

\section{TABLE I}

Dimensions of anatomical structures of female specimens of Lutzomyia intermedia, prepared with Berlese's or Nelson Cerqueira (NC) fluids

\begin{tabular}{|c|c|c|c|c|c|c|c|c|c|}
\hline \multirow[b]{3}{*}{ Structures } & \multicolumn{8}{|c|}{ Preparation method } & \multirow[b]{3}{*}{ Berl./NC } \\
\hline & \multicolumn{4}{|c|}{ Berlese } & \multicolumn{4}{|c|}{$\mathrm{NC}$} & \\
\hline & Mean & S. D. & $\mathrm{N}$ & C. V. & Mean & S. D. & $\mathrm{N}$ & C. V. & \\
\hline Head width $^{b}$ & 389 & 11,7 & 20 & 3 & 374 & 9,5 & 10 & 2,6 & 1,03 \\
\hline Cibarium width ${ }^{a}$ & 52,6 & 4,1 & 23 & 7,7 & 49,6 & 3,5 & 14 & 7,1 & 1,06 \\
\hline Eye width ${ }^{a}$ & 136 & 6,5 & 23 & 4,8 & 129 & 6,9 & 11 & 5,3 & 1,05 \\
\hline Mesonotum length $^{a}$ & 636 & 3,1 & 24 & 0,49 & 616 & 13 & 13 & 2,1 & 1,03 \\
\hline
\end{tabular}

S. D.: standard deviation; N: number of measured specimens; C. V.: coeficient of variation; $a$ : significance at $5 \%$ $b$ : significance at $1 \%$.

TABLE II

Dimensions of anatomical structures of male specimens of Lutzomyia intermedia, mounted with Berlese's or Nelson Cerqueira (NC) fluids

\begin{tabular}{|c|c|c|c|c|c|c|c|c|c|}
\hline \multirow[b]{3}{*}{ Structures } & \multicolumn{9}{|c|}{ Preparation method } \\
\hline & \multicolumn{4}{|c|}{ Berlese } & \multicolumn{4}{|c|}{$\mathrm{NC}$} & \multirow[b]{2}{*}{ Berl./NC } \\
\hline & Mean & S. D. & $\mathrm{N}$ & C. V. & Mean & S. D. & $\mathrm{N}$ & C. V. & \\
\hline Head width $^{b}$ & 356 & 9,1 & 15 & 2,6 & 333 & 13,6 & 11 & 4,1 & 1,07 \\
\hline Distance between eyes $b$ & 93 & 4,6 & 15 & 5 & 100 & 6,7 & 11 & 6,7 & 0,93 \\
\hline Antenomere III $^{a}$ & 264 & 11,3 & 13 & 4,3 & 249 & 15,2 & 8 & 6,1 & 1,06 \\
\hline Total length palps ${ }^{b}$ & 498 & 16,8 & 16 & 3,4 & 480 & 16,62 & 11 & 3,5 & 1,04 \\
\hline Length eyes $^{a}$ & 225 & 8,7 & 16 & 3,9 & 213 & 15,1 & 12 & 7,1 & 1,06 \\
\hline Width eyes ${ }^{b}$ & 132 & 5 & 16 & 3,8 & 117 & 6,2 & 11 & 5,3 & 1,13 \\
\hline $\mathrm{a}^{a}$ & 480 & 35,8 & 15 & 7,5 & 511 & 28,3 & 12 & 5,5 & 0,94 \\
\hline$d^{a}$ & 228 & 42,2 & 15 & 18,5 & 261 & 23,5 & 12 & 9 & 0,87 \\
\hline Length posterior femur ${ }^{a}$ & 772 & 35,3 & 15 & 4,6 & 746 & 27,4 & 12 & 36,7 & 1,04 \\
\hline Length genital filaments ${ }^{a}$ & 323 & 19,6 & 16 & 6 & 308 & 12,1 & 13 & 3,9 & 1,05 \\
\hline Maximal w. genital pump ${ }^{a}$ & 78,6 & 8,3 & 16 & 10,5 & 72,2 & 6,3 & 13 & 8,8 & 1,09 \\
\hline
\end{tabular}

S. D.: standard deviation; N: number of measured specimens; C. V.: coeficient of variation; W: width; a: length of $\mathrm{R}_{2}$; d: distance between the bifurcation of $\mathrm{R}_{2+3}$ and distal extremity of $\mathrm{R}_{1} ; a$ : significance at $5 \%$; $b$ : significance at $1 \%$. 